\title{
Electrophoresis of Egg White Proteins of the Japanese and the Formosan Native Fowls.
}

\author{
Masao Kimura \\ Faculty of Agriculture, Gifu University, Kakamigahara, Gifu
}

$\mathrm{G}_{3}$ ovoglobulins of the egg white from the domestic fowl are controlled by the $G_{3}$ locus. Initial reports indicated that this locus had two co-dominant allelent $G_{3}{ }^{A}$ and $G_{3}{ }^{B 1,2}$. Subsequent works revealed other variants, and at present as many as ten different variants can be distinguished by starch gel electrophoresis ${ }^{3}$.

Although there is no obvious relationship between the egg white polymorphisms and any economical traits, the globulins are of interest phylogenetically ${ }^{4}$.

This report describes a new variant of $\mathrm{G}_{3}$ ovoglobulin and other proteins of of the egg white from the five breeds of the chicken.

Eggs of Formosan native fowls were collected from Holi, Taichung and Chung-Li, TAOyun, Taiwan. The egg from four breeds of Japanese fowl were also examined. For the comparison, few eggs from White Leghorn were collected. Thin egg white was subjected to starch gel electrophoresis. Ferguson and Wallace's buffer system $^{5 \text { ) }}$ was employed and the gel was stained in Amido Black $10 \mathrm{~B}$.

A new variant $\left(\mathrm{G}_{3} \mathrm{~F}\right)$ of $\mathrm{G}_{3}$ ovoglobulin was observed in one Shamo and one Formosan native fowl (Fig. 1.). This variant had faster electrophoretic mobility than $\mathrm{G}_{3} \mathrm{~A}$. These two birds showed phenotype $\mathrm{G}_{3} \mathrm{AF}$. Three $\mathrm{G}_{3}$ variants that have faster mobilities than $\mathrm{G}_{3} \mathrm{~A}$ have been reported, namely $\mathrm{G}_{3} \mathrm{~A}^{\mathrm{F}},^{3)} \mathrm{G}_{3} \mathrm{~J}^{6)}$ and $\mathrm{G}_{3} \mathrm{M}^{7}$. Judging from the mobility, the variant $\mathrm{G}_{3} \mathrm{~F}$ may be correspond to $\mathrm{G}_{3} \mathrm{~J}$.

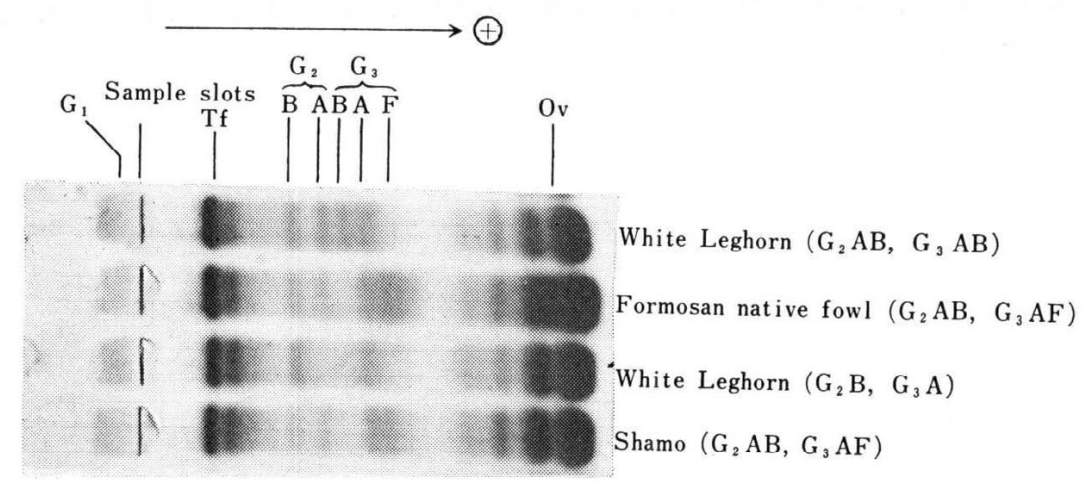

Fig. 1. Starch gel electrophoretic separation of egg white protein.

The $\mathrm{J}$ variant has been found first in the Red Jungle Fow ${ }^{6}$ ) and then in the Yokohama (Japanese Long Tailed Fowl) and the Japanese Bantam ${ }^{8)}$. In addition to above findings, BAKer et al. ${ }^{9)}$ reported the presence of $\mathrm{G}_{3} \mathrm{~J}$ in some Indian village fowl and they 
Table 1. Phenotypes of egg white protoins in various of the chicken.

\begin{tabular}{|c|c|c|c|c|c|c|c|c|c|c|c|}
\hline \multirow[t]{2}{*}{ Breed } & \multirow[t]{2}{*}{ No. hens } & \multicolumn{3}{|c|}{$\mathrm{G}_{2}$} & \multicolumn{4}{|c|}{$\mathrm{G}_{3}$} & \multicolumn{3}{|c|}{ Tf } \\
\hline & & A & $\mathrm{AB}$ & B & $\mathrm{AF}$ & A & $\mathrm{AB}$ & $\mathrm{B}$ & $\mathrm{B}$ & $\mathrm{BC}$ & $\mathrm{C}$ \\
\hline \multicolumn{12}{|l|}{ Formosan native fowl } \\
\hline 1. Tachung & 3 & & 3 & & 1 & 2 & & & 3 & & \\
\hline 2. TAOYUAN & 1 & & 1 & & & 1 & & & & 1 & \\
\hline Shamo (Japanese Game) & 1 & & 1 & & 1 & & & & 1 & & \\
\hline Chabo (Japanese Bantan) & 11 & & 1 & 10 & & 9 & 2 & & 11 & & \\
\hline Gifu-Jitori (Japanese native fowl) & 24 & 6 & 14 & 4 & & & 8 & 16 & 24 & & \\
\hline Silkies & 8 & 1 & 5 & 2 & & 8 & & & 6 & 2 & \\
\hline
\end{tabular}

explained that the presence of $\mathrm{G}_{3} \mathrm{~J}$ in the these breeds was suggestive of an Asiatic origin for this variant. The present results may support their explanation, but it is desirable to compare the $\mathrm{G}_{3} \mathrm{~F}$ with the previously established variants.

The $\mathrm{G}_{3}{ }^{B}$ allele seems to be associated with Asiatic ancestry ${ }^{4}$. High frequency of $G_{3}{ }^{B}$ was observed only in the Gifu-Jitori (Japanese native fowl). $G_{3}{ }^{A}$ were predominant in other four breeds. Five breeds examined were monomorphic for $O \mathrm{v}^{A}$ and $G_{1}{ }^{F}$. Two Silkies and one Formosan native fowl had two protein bands in the transferrin rigeon.

\section{References}

1) Lush, I. E.: Nature, 189, 981, 1961.

2) Baker, C. M. A. and C. Manwell: Brit. Poult. Sci. 3, 161, 1962.

3) Baker, C. M. A., G. Croizier, A. Stratil and C. Manwell: Adv. Genet. 15, 147, 1970.

4) BAKER, C. M. A.: The proteins of egg white. In "Egg Quality: A study of the Hen's Egg" (T. C. Carter, ed.), pp. 67-108. Oliver \& Boyd, Edinburgh and London. 1968.

5) Ferguson, K. A. and A. L. C. Wallace: Nature, 190, 6291961.

6) Baker, C. M. A.: Comp. Biochem. Physiol. 12, 389, 1964.

7) Croizier, G.: Annls Biol. anim. Biochem. Biophys. 6, 379, 1966.

8) BAKer, C. M. A.: Personal communication, 1972.

9) Baker, C. M. A., C. Manwell, N. Jayaprakash and N. Francis: Comp. Biochem. Physiol. 40 B, $147,1971$. 